\title{
KETERKAITAN DANA DESA TERHADAP KEMISKINAN DI KABUPATEN LOMBOK UTARA
}

\author{
The Relationship of Village Funds to Poverty \\ in North Lombok Regency
}

\section{Adi Artino ${ }^{1}$, Bambang Juanda, Sri Mulatsih}

\begin{abstract}
Abstrak: Kemiskinan merupakan salah satu tolak ukur kinerja pembangunan pemerintah, dari sisi kesejahteraan masyarakat. Penyebab terjadinya kemiskinan dikarenakan tidak meratanya distribusi pendapatan serta ketimpangan pembangunan. Program dana desa untuk masingmasing desa diduga dapat memberikan implikasi positif bagi kesejahteraan masyarakat. Penelitian ini bertujuan untuk melihat hubungan dana desa dengan kemiskinan di Kabupaten Lombok Utara. Metode yang digunakan adalah geographically weigthed regression (GWR). Dana desa dapat mengurangi kemiskinan di setiap desa di Kabupaten Lombok Utara, namun tidak berpengaruh signifikan karena model yang dihasilkan masih dipengaruhi oleh variabel lain diluar model. Koefisien variabel jumlah sarjana dan sawah di setiap desa dapat mengurangi kemiskinan dan juga di beberapa Desa dapat meningkatkan kemiskinan. Diperlukan variasi kebijakan penanggulangan kemiskinan di masing-masing desa.
\end{abstract}

\section{Kata kunci: Dana Desa, Kemiskinan, Autokorelasi Spasial}

\begin{abstract}
Poverty is one of the indicator of development performance, in terms of community welfare. Cause of poverty due to uneven distribution of income and inequality of development. Village funding programs for each village provide positive implications for community welfare. This study aims to see the relationship of village funds to poverty in North Lombok Regency. The method used is geographically weighted regression (GWR). Village funds can reduce poverty in each village in North Lombok Regency, but it does not have a significant effect in reducing poverty because the resulting model is still influenced by other variables outside the model. The variable coefficient of the number of bachelor and paddy fields in each village can reduce poverty and some can increase poverty. So there is a need for policy variation to reduce poverty in each village.
\end{abstract}

Keywords: Village Funds, Poverty, Spasial Autocorrelation

\section{PENDAHULUAN}

Kemiskinan merupakan salah satu tolak ukur kinerja pembangunan pemerintah, dari sisi kesejahteraan masyarakat. Penyebab terjadinya kemiskinan dikarenakan tidak meratanya distribusi pendapatan serta ketimpangan pembangunan. Irawan, et al (2013) berpendapat bahwa kemiskinan sebagai pemicu berbagai permasalahan lingkungan dan sosial. Berbagai upaya untuk penanggulangan kemiskinan masih bersifat programatis dan belum menyentuh aspek atau dimensi spasial kemiskinan. Sartika, et al(2016) menerangkan bahwa kemiskinan pedesaan menjadi masalah utama dalam proses pelaksanaan pembangunan di daerah pedesaan dan sebagian besar penduduk miskin tinggal di perdesaan.

\footnotetext{
${ }^{1}$ Ilmu Perencanaan Pembangunan Wilayah dan Perdesaan Sekolah Pascasarjana IPB
} 
Menurut Iryanti (2014) menerangkan bahwa sebagai besar yang menyebabkan masyarakat perdesaan miskin karena masih banyak yang bekerja di sektor pertanian, jika dilihat dari perbandingan segi pendapatan pertanian dan non pertanian, maka pendapatan di non pertanian lebih menjanjikan seperti sektor perdagangan, industri, konstruksi dan transportasi. Nurjihadi dan Dharmawan (2016) mengungkapkan dalam teori lingkaran setan kemiskinan yang diungkapkan dalam petani memiliki posisi tawar yang rendah yang selanjutnya akan menyebabkan pendapatan rendah, penumpukan hutang serta kemampuan akumulasi modal yang terbatas dan menyebabkan petani menjadi miskin. Secara umum dapat dilihat bahwa sebagian besar masyarakat yang bertani hidup dalam kemiskinan. Petani yang bekerja sepenjang hari hanya menerima upah yang seidkit dan tidak sebanding dengan apa yang dikerjakan (Sahdan,2005). Penambahan luas lahan sawah pada setiap desa atau percetakan sawah baru yang direncanakn pemerintah dalam rangka meningkatkan swasembada beras apakah nanti akan pro terhadap rakyat kecil dan apakah mampu mengurangi kemiskinan.

Sayogyo (1977) mendefinisikan kemiskinan sebagai jumlah penduduk yang memiliki pendapatan perkapita yang tidak mencukupi untuk mengkonsumsi barang dan jasa yang nilainya ekuivalen dengan $20 \mathrm{~kg}$ beras untuk daerah perdesaan dan $30 \mathrm{~kg}$ beras untuk daerah perkotaan. Nurwati (2008) menyatakan bahwa kemiskinan merupakan masalah multidimensi karena berkaitan dengan ketidakmampuan akses secara ekonomi, sosisal budaya, politik serta partisipasi masyarakat. Berdasarkan beberapa teori tersebut dapat disimpulkan bahwa kemiskinan adalah suatu keadaan individu atau masyarakat yang tidak bisa memenuhi kebutuhan dasar baik secara materil dan non materil karena katerbatasan akan sumber daya yang ada.

Pemberantasan kemiskinan bukan hanya menjadi perhatian pemerintah daerah saja melainkan juga menjadi perhatian pemerintah pusat. Banyak program yang dilakukakan oleh pemerintah pusat untuk mengurangi jumlah kemiskinan, terutama untuk wilayah perdesaan, seperti tercantum pada Undang-Undang No. 6 Tahun 2014 tentang Desa. Dalam undangundang tersebut desa diberi kewenangan khusus dalam mengelola wilayah serta diberikan sejumlah dana yang disebut dana desa sebagai penunjang kinerja dalam pembangunan, selain alokasi dana desa (ADD), dana hibah desa, serta dana retribusi/pajak yang sah. Pemberian dana desa diharapkan mampu memberi efek yang besar dalam pembangunan dan perubahan perekonomian di setiap Desa. Kewajiban setiap desa untuk memiliki badan usaha milik desa (Bumdes) diharapkan mampu membuat desa menjadi mandiri dalam perekonomian serta menyerap banyak tenaga lokal.

Data dari Badan Pusat Statistik (BPS, 2016) menunjukkan bahwa kemiskinan tertinggi berada di wilayah perdesaan dengan jumlah kemiskinan pada tahun 2015 mencapai 17 juta jiwa. sedangkan tingkat kemiskinan di kawasan perkotaan mencapai 10 juta jiwa. Hal ini dikarenakan sebagian besar masyarakat desa berpanghasilan rendah dan mereka bekerja sebagai buruh tani dan buruh kasar. Kondisi perekonomian suatu negara atau daerah adalah cerminan dari kesejateraan masyarakat yang tinggal pada negara atau daerah tersebut (Cristianto,2013). Selain itu menurut Kotze (dalam Hikmat,2004) menerangkan rata-rata masyarakat miskin tinggal terisolasi dan membutuhkan pemberdayaan yang intes dan biasanya tinggal di daerah perdesaan.

Kabupaten Lombok Utara merupakan Kabupaten termuda di Provinsi Nusa Tenggara Barat yang memiliki bentang alam yang sangat baik mulai dari garis pantai yang panjang, pegunungan, sawah serta hutan yang merupakan sumber daya alam yang potensial untuk dikelola. Akan tetapi dengan sumber daya alam yang melimpah tersebut kemiskinan masih saja menjadi masalah yang serius. Hal ini dapat dilihat dari kenaikan jumlah kemiskinan di Kabupaten Lombok Utara. Pada tahun 2015 menurut Badan Pusat Statistik (BPS, 2016) yaitu kemiskinan pada tahun 2015 sebesar 34,17\%, dibandingkan dengan tahun 2014 sebesar 34\%, naik sebesar 0,17\%. Pada tahun 2010 sampai dengan tahun 2014 terjadi penurunan 
tingkat kemiskinan yang sangat signifikan tetapi tidak bisa dipertahankan pada tahun 2015 . Dimana pada tahun 2014 sudah berlakunya Undang-undang No. 6 Tahun 2014 yang mengatur tentang adanya bantuan dana desa untuk setiap Desa di seluruh Indonesia. Hal ini diduga juga menjadi salah satu yang menyebabkan kenaikan kemiskinan karena formulasi untuk pemberian dana desa yaitu tingkat kemiskinan, jumlah penduduk, kesulitan geografis dan luas wilayah. Secara spasial kenaikan tingkat kemiskinan pada suatu wilayah dipengaruhi oleh wilayah lain yang menjadi tetangganya karena ada faktor kedekatan atau ketetanggan antar wilayah tersebut. Berdasarkan hukum I Tobler yang menyatakan bahwa semua hal saling berkaitan, tetapi sesuatu yang dekat akan memiliki kaitan yang lebih dari pada sesuatu yang jauh (Tobler, 1970). Oleh sebab itu, diperkirakan terjadi keterkaitan wilayah dengan jumlah persentase kemiskinan di Kabupaten Lombok Utara, sehingga peneliti ingin melihat pola dan hubungan secara spasial kemiskinan yang ada di Kabupaten Lombok Utara karena pendekatan wilayah atau analisis spasial harus digunakan untuk melihat solusi atau kebijakan yang tepat untuk penanggulangan kemiskinan.

Amanat undang-undang No.6 Tahun 2014 tentang Desa. Secara umum dapat dijelaskan bahwa tujuan pemberian dana desa untuk mengurangi ketimpangan antardesa, dimana tujuan pemberian dana desa untuk meningkatkan kesejahteraan dan pemerataan pembangunan desa melalui peningkatan pelayanan publik, memajukan perekonomian desa, mengatasi kesenjangan pembangunan antar desa, serta memperkuat masyarakat desa sebagai subyek dari pembangunan. Berdasarkan data dari kementerian keuangan bahwa dari tahun 2015 anggaran untuk dana desa mengalami knaikan yang signifikan pada tahun 2015 dari 20,76 triliun menjadi 46,98 triliun di tahun 2016 dan pada tahun 2017 kembali mengalami kenaikan menjadi 60 triliun. Besarnya jumlah dana desa yang diterima oleh setiap desa diharapkan mampu mewujudkan amanat undang-undang dan dipergunakan sesuai dengan peruntukannya.

Tingkat pendidikan penduduk miskin atau kelompok ekonomi $40 \%$ terbawah yang rendah menyebabkan kurang kompetitif dalam mendapatkan pekerjaan yang layak dan secara lingkaran setan kemiskinan akan menyebabkan daya beli rendah, pengetahuan rendah dan produksi rendah dan akan terus berulang. Zahdiyati \& David (2017) dalam penelitiannya mengungkapkan bahwa indeks pembangunan manusia (IPM) sangat berpengaruh terhadap kemiskinan, jika IPM suatu daerah tinggi maka kemiskinan di daerah tersebut rendah. Hal ini yang mendasari peneliti ingin menambah variabel jumlah sarjana dan luas lahan sawah untuk melihat penanggulangan kemiskinan di Kabupaten Lombok Utara. Kemiskinan yang ada di desa membuat masyarkatnya rela melakukan apa saja untuk bertahan hidup (James, 1981). Kemiskinan adalah persoalan yang sangat kompleks dan kronis yang membutuhkan analisis serta variabel yang tepat dalam rangka penanggulangan kemiskinan (Prawoto,2009).

Ada beberapa variabel yang digunakan oleh peneliti yaitu variabel dependennya adalah kemiskinan serta variabel independennya dana desa (rasio), jumlah sarjana (rasio) dan luas sawah (rasio). Sesuai dengan uraian sebelumnya, maka tujuan penelitian ini adalah: (1). Menganalisis hubungan dana desa terhadap kemiskinan di kabupaten Lombok Utara. (2). Mengetahui variabel - variabel yang siginfikan mempengaruhi kemiskinan di Kabupaten Lombok Utara?

\section{METODE PENELITIAN}

\section{Data dan Sumber Data}

Data yang digunakan dalam penelitian ini adalah data sekunder yang didapat dari instansi terkait seperti data dana desa diperoleh dari Badan Pemberdayaan Masyarakat dan Pemerintahan Desa (BPMPD) Kabupaten Lombok Utara, data jumlah sarjana dan jumlah 
penduduk diperoleh Dinas Kependudukan dan Pencatatan Sipil (Dukcapil) Kabupaten Lombok Utara, dan data luas lahan sawah diperoleh dari Badan Perencanaan Pembangunan Daerah (Bappeda) Kabupaten Lombok Utara. Sedangkan untuk data kemiskinan digunakan data dari Tim Nasional Percepatan Penanggulangan Kemiskinan (TNP2K).

\section{Identifikasi autokorelasi spasial kemiskinan di Kabupaten Lombok Utara}

Karakteristik kemiskinan antar desa di Kabupaten Lombok Utara dianalisis menggunakan Indeks Moran untuk melihat penyebaran pola kemiskinan antar desa atau dependensi spasialnya. Adapun formula untuk menghitung Indeks Morran sebagai berikut:

$$
I=\frac{n \sum_{i=1}^{n} \sum_{j=1}^{n} w_{i j}\left(x_{i}-\bar{x}\right)\left(x_{j}-\bar{x}\right)}{\sum_{i=1}^{n}\left(x_{i}-\bar{x}\right)^{2}}
$$

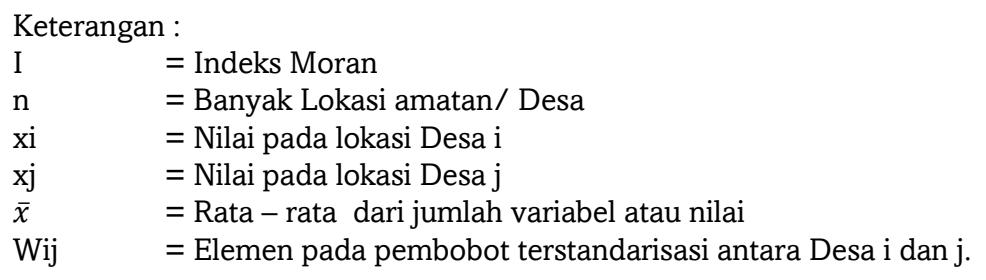

\section{Analisis Keterkaitan Dana Desa terhadap Kemiskinan di Kabupaten Lombok Utara}

Peran pemerintah Desa dalam mengelola dana desa yang sesuai dengan peruntukan akan memberikan dampak yang positif untuk pembangunan ekonomi secara umum. Menurut Mahfudz (2014) alokasi dana desa memiliki nilai positif dan multiflier effect yang sangat signifikan dalam pengelolaan dan perbaikan infrastruktur, peningkatan pengetahuan masyarakat, serta meningkatnya partisipasi masyarakat dalam pembangunan desa dan juga menyebabkan banyak terserapnya tenaga kerja lokal. Adanya tambahan dana desa dalam alokasi keuangan desa memberikan dampak positif untuk mencapai tujuan kesejahteraan masyarakat. Penelitian Prasetyanto (2012) menyimpulkan bahwa pelaksanaan alokasi dana desa (ADD) yang diatur secara seragam dan dengan cara persentase, ternyata kurang tepat untuk mengentaskan kemiskinan dan mengatasi kesenjangan antar desa. Pemberian ran serta proporsi dana desa memiliki dampak yang sangat baik untuk proses penanggulangan kemiskinan ditingkat desa. Oleh karena itu, penelitian ini menggunakan dana desa sebagai variabel serta penambahan variabel lain seperti jumlah sarjana setiap desa serta luas sawah perdesa sebagai variabel lainnya karena secara tidak langsung peran masyarakat yang memiliki tingkat pendidikan sarjana sangat dibutuhkan untuk mempercepat pertumbuhan ekonomi, selain itu luas lahan sawah digunakan karena PDRB utama Kabupaten Lombok Utara adalah sektor pertanian sehingga peneliti tertarik untuk memasukkan variabel luas lahan sawah perdesa. Model yang digunakan adalah Geographically Weighted Regression (GWR). Model operasional yang digunakan adalah:

$$
\text { Kemiskinan }_{i}=b_{0}(u i, v i)+b_{1}\left(\text { ui,vi) } D_{D_{i}}+b_{3}\left(\text { ui,vi) } J_{i}+b_{5}(\text { ui,vi) Luas Sawah } i\right.\right.
$$

\footnotetext{
Keterangan:

Kemiskinan $_{\mathrm{i}} \quad=$ Persentase penduduk miskin di setiap Desa $(\%)$

$\mathrm{DD}_{\mathrm{i}} \quad$ = Dana desa perpenduduk dibagi total dana desa perdesa (rasio)

JS $\quad$ = Jumlah sarjana dibagi jumlah penduduk (Rasio)

Luas Sawah $_{\mathrm{i}} \quad$ = jumlah sawah dibagi luas desa (Rasio)

bo $\quad$ intercept
} 
$\begin{array}{ll}\mathrm{b}_{1} \ldots . . \mathrm{b}_{3} & =\text { koefisien Peubah masing masing lokasi } \\ \text { (ui,vi) } & =\text { kooerdinat lintang, bujur dari titik ke }- \text { i pada lokasi }\end{array}$

Secara umum pada model GWR diasumsikan bahwa data spasial yang dekat dengan titik ke-i mempunyai pengaruh yang besar pada penaksiran dari $b_{1 . .3}$ (ui,vi) dari pada yang berada jauh dari titik ke-i.

\section{HASIL DAN PEMBAHASAN}

Hasil analisis autokorelasi spasil dengan uji Indeks Moran membuktikan bahwa adanya autokorelasi spasial positif, hal ini menunjukkan bahwa ada keterkaitan nilai persentase penduduk miskin antar desa di Kabupaten Lombok Utara. Sedangkan pola kemiskinan yang terbentuk adalah mengelompok (Clustered) dengan nilai Indeks Moran sebesar 0,206292 lebih besar dari expected Index yaitu -0,031250 yang dapat dilihat pada Tabel 1.

Tabel 1. Hasil Indeks Moran

\begin{tabular}{cc}
\hline Moran'Index $(I)$ & 0,206292 \\
Expected Index $\left(I_{0}\right)$ & $-0,031250$ \\
Variace & 0,004683 \\
Z-score & 3,471064 \\
p-value & 0,000518 \\
\hline
\end{tabular}

Sumber : Data diolah, 2017

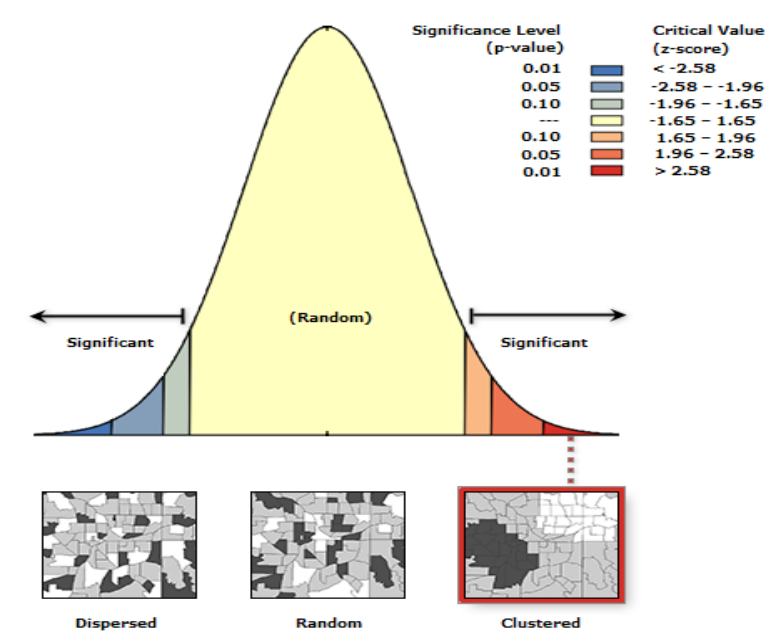

Sumber: Data diolah

\section{Gambar 1. Hasil Indeks Moran}

Secara lokal dapat dilihat pada Gambar 2 terdapat empat desa yang memiliki persentase penduduk miskin tinggi dan dikelilingi oleh desa dengan persentase penduduk miskin yang tinggi juga (High-High) diantaranya Desa Selengan, Desa Akar-Akar, Desa Sukadana, dan Desa Senaru, sedangkan untuk persentase penduduk miskin yang rendah dan dikelilingi oleh persentase penduduk miskin yang rendah (Low-Low) terdiri dari dua desa yaitu Desa Gili Indah dan Desa Teniga. 


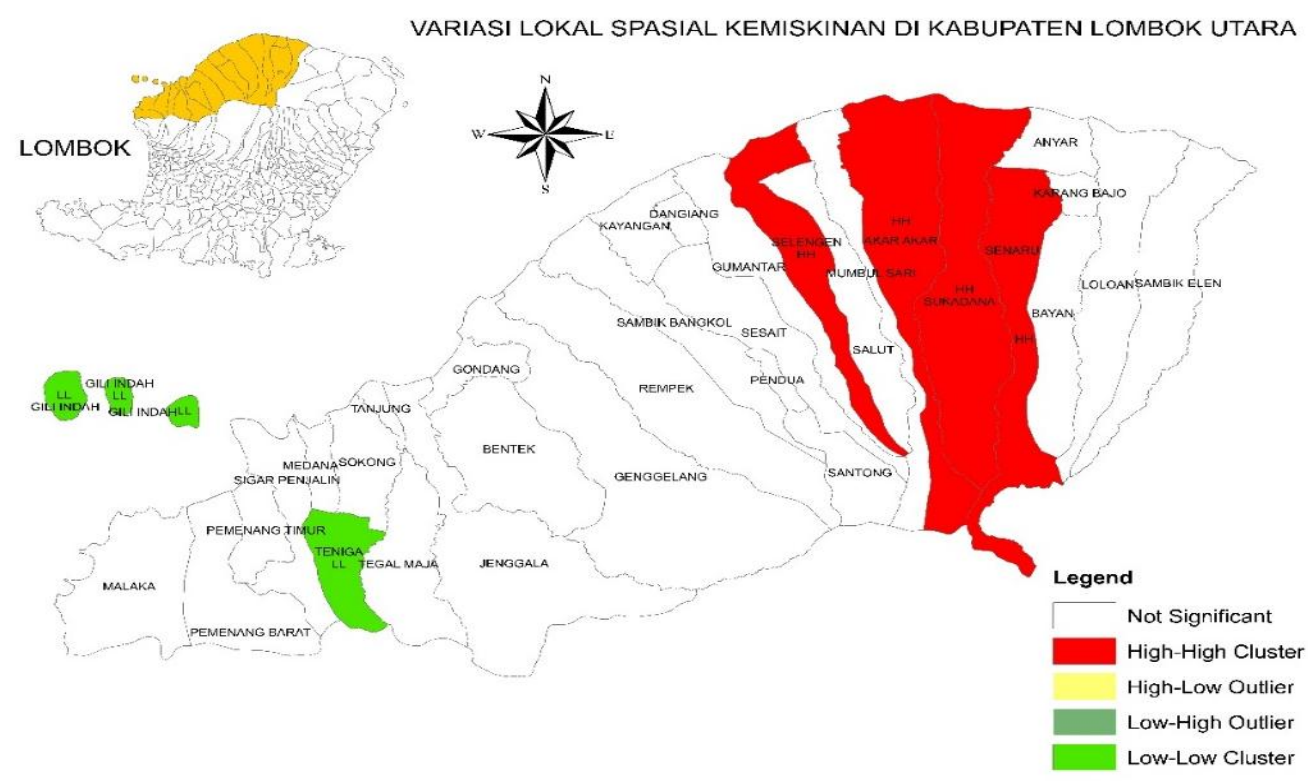

Sumber: Hasil Analisis

Gambar 2. Variasi Lokal Spasial Kemiskinan di Kabupaten Lombok Utara

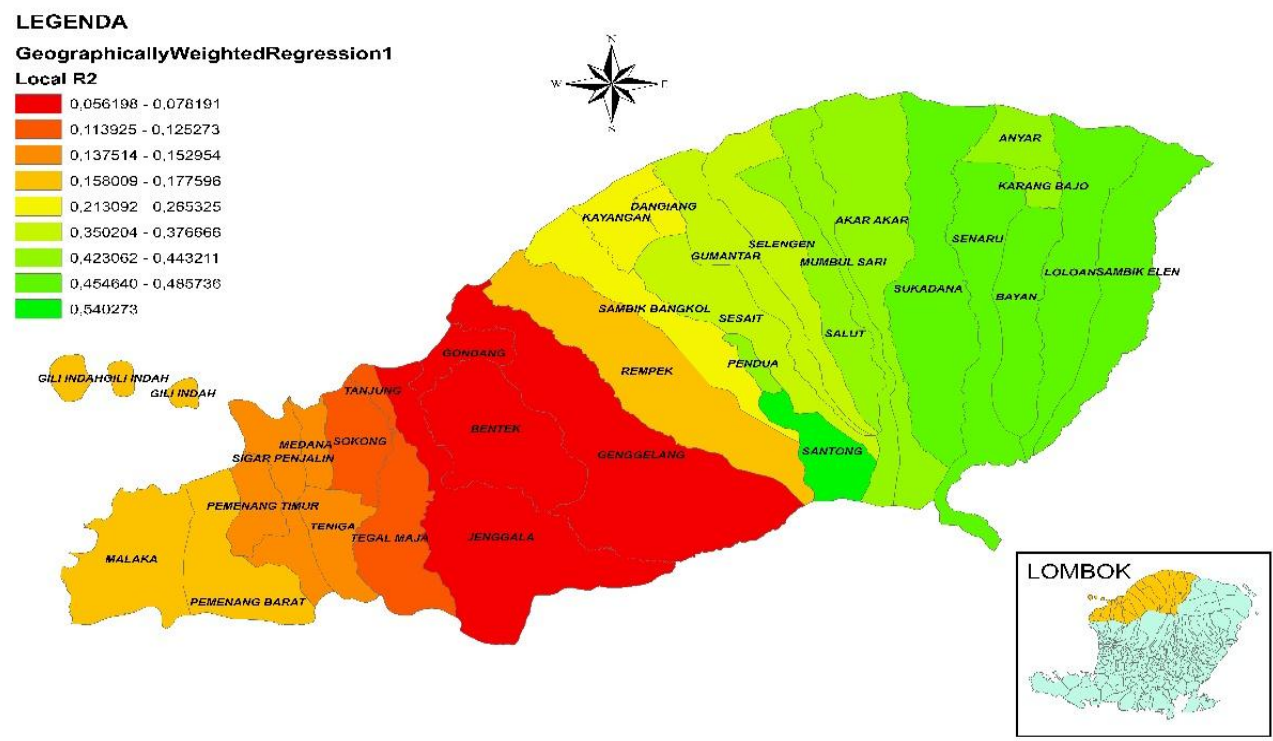

Sumber: Hasil Analisis

\section{Gambar 3. Variasi Lokal R2 Dugaan Model GWR Keterkaitan Dana Desa Terhadap Kemiskinan di Kabupaten Lombok Utara.}

Secara lokal distribusi nilai R2 pada setiap model GWR untuk setiap lokasi amatan memiliki nilai yang berbeda beda. Nilai R2 yang terendah berada di Desa Bentek dengan nilai 0,0561 atau 5,6\% yang artinya kemampuan parameter model GWR pada Desa Bentek hanya mampu menjelaskan variasi persentase kemiskinan sebesar 5,6\% sedangkan sisanya dipengaruhi oleh variabel lain diluar model. Sedangkan nilai R2 yang paling tinggi yaitu di Desa Santong dengan nilai R2 sebesar 0,5402 atau 54\% artinya kemampuan parameter model GWR hanya mampu menjelaskan variasi persentase kemiskinan sebesar 54\% dan sisanya dipengaruhi oleh variabel diluar model. Secara umum model GWR belum maksimal karena masih banyak variabel lain yang mempengaruhi kemiskinan di setiap desa di Kabupaten Lombok Utara. Selain itu variasi 
nilai R2 secara lokal menandakan bahwa setiap wilayah menjelaskan kejadian kemiskinan untuk setiap desa sehingga perlu adanya kebijakan yang berbeda-beda.

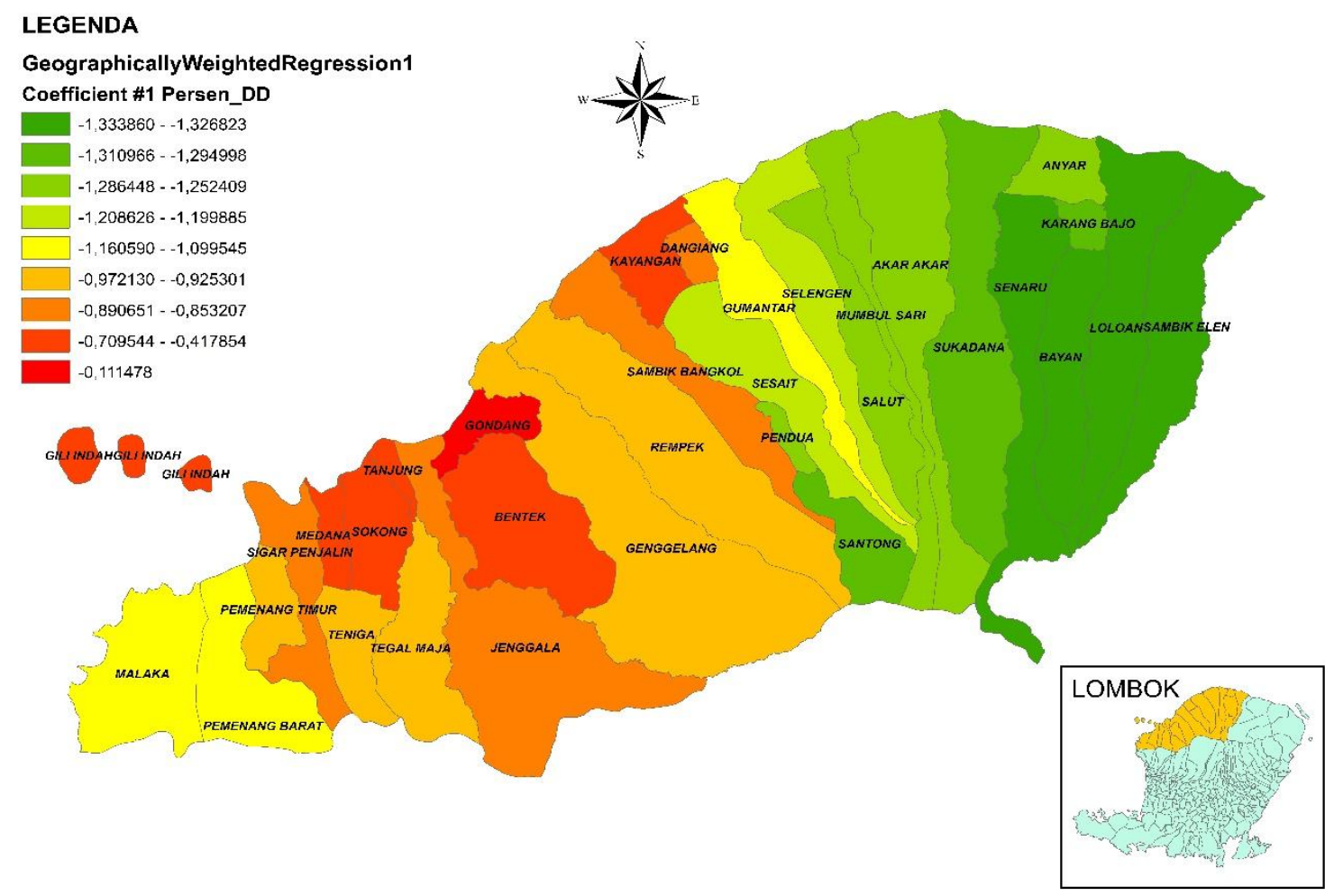

Sumber: Hasil Analisis

Gambar 4. Variasi Spasial Dugaan Model GWR Keterkaitan Dana Desa Terhadap Kemiskinan.

Hasil permodelan GWR untuk melihat keterkaitan dana desa terhadap kemiskinan di Kabupaten Lombok Utara memberikan hasil dugaan yang berbeda pada setiap unit amatan desa. Jika dana desa memiliki nilai atau hubungan yang negatif menjelaskan bahwa setiap penambahan jumlah dana desa di setiap desa akan menyebabkan kemiskinan di desa tersebut berkurang. Pada Gambar 4 menjelaskan bahwa secara umum distribusi nilai parameter koefisien dana desa mampu mengurangi kemiskinan di desa paling tinggi terdapat di Desa Senaru, Desa Bayan, Desa Loloan, dan Desa Sambik Elen yang ditunjukkan dengan warna hijau. Sedangkan untuk desa yang paling rendah nilai parameter koefisien dana desa yaitu Desa Gondang dengan warna merah.

Pada gambar 5 menjelaskan bahwa distribusi parameter koefisien sarjana pada wilayah bagian timur dengan nilai paling tinggi yaitu -8,725567 sampai -7,699135 yang ditunjukkan pada warna hijau berarti desa tersebut mampu mengurangi kemiskinan untuk setiap kenaikan satu satuan sarjana. Sedangkan pada bagian barat mulai dari warna orange sampai merah menjelaskan bahwa setiap kenaikan satu satuan sarjana akan meningkatkan kemiskinan pada desa tersebut. Selain itu pada Gambar 6 menjelaskan bahwa koefisien parameter luas sawah yang dapat mengurangi kemiskinan untuk setiap penambahan satu satuan luas sawah yaitu berada pada bagian barat yaitu di Desa Santong, Senaru, Loloan dan Sambik Elen. Sedangkan untuk kenaikan setiap satu satuan luas lahan sawah yang menambah angka kemiskinan berada di wilayah timur yang paling tinggi yaitu Desa Gili Indah, Pemenang Barat dan Timur, Malaka, Medana, Sigar Penjalin dan Teniga dengan warna merah, selain itu 


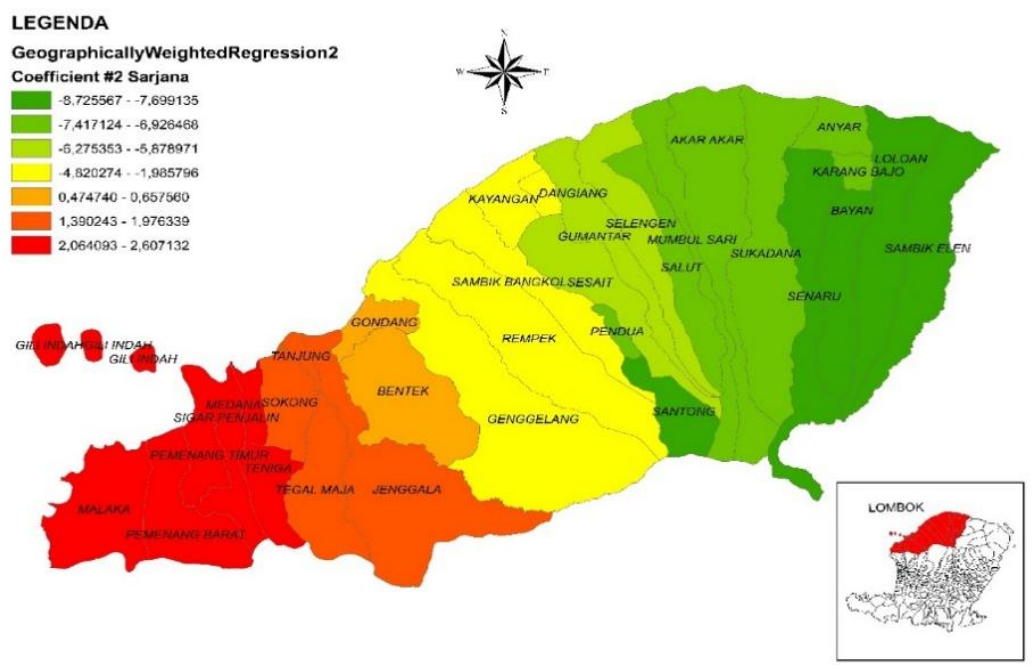

Sumber: Hasil Analisis

Gambar 5. Variasi Spasial Dugaan Model GWR Keterkaitan Sarjana Terhadap Kemiskinan.

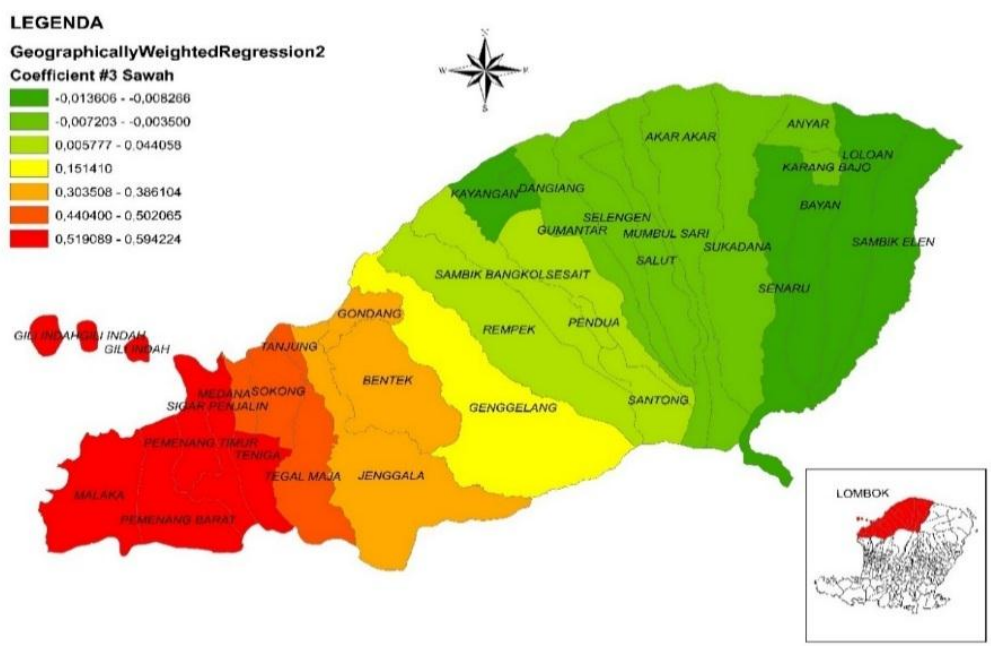

Sumber: Hasil Analisis

Gambar 6. Variasi Spasial Dugaan Model GWR Keterkaitan Luas Sawah terhadap Kemiskinan.

Variasi distribusi parameter koefisien hasil GWR menunjukkan perlu adanya perlakukan atau kebijakan yang berbeda-beda dalam mengalokasikan dana desa, jumlah sarjana dan luas lahan sawah pada setiap desa di Kabupaten Lombok Utara. Generalisasi sebuah kebijakan dalam mengalokasikan dana desa, peningkatan jumlah sarjana, luas lahan sawah tanpa memperhatikan variasi pengaruh dari nilai paremeter/variabel tersebut akan memberikan dampak pertumbuhan penduduk miskin, sehingga upaya dalam percepatan penanggulangan kemiskinan tidak terlaksana dengan baik. 


\section{KESIMPULAN}

Kemiskinan di Kabupaten Lombok Utara memiliki pola yang mengelompok pada masing-masing wilayah karena nilai autokorelasinya bersifat positif. Variabel dana desa pada masing-masing desa amatan mampu menurunkan kemiskinan, akan tetapi tidak signifikan karena memerlukan waktu yang panjang minimal 5 tahun sampai 10 tahun untuk merasakan pembangunan dengan anggaran dana desa. Dana desa untuk saat ini belum berjalan 5 tahun. Variabel jumlah sarjana dan luas sawah pada setiap desa ada yang dapat mengurangi kemiskinan di setiap desa dan ada yang dapat menambah kemiskinan. Sehingga perlu adanya variasi kebijakan pada masing-masing desa amatan agar kebijakan yang sudah dibuat bisa tepat sasaran.

\section{DAFTAR PUSTAKA}

[BPS] Badan Pusat Statistik. 2016. Jumlah Penduduk Miskin menurut Provinsi dari Tahun 2013 - 2016. [diunduh pada 2016 Oktober 10]. Tersedia pada: https://www.bps.go.id/linkTableDinamis/view/id/1119.

[BPS] Badan Pusat Statistik. 2016. Jumlah Penduduk Miskin di Kabupaten Lombok Utara periode 2010 - 2015.

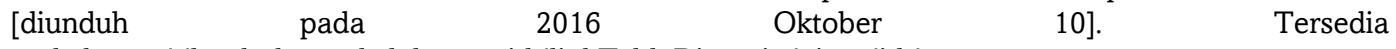
pada:https://lombokutarakab.bps.go.id/linkTableDinamis/view/id/219.

Hikmat, H. 2004. Strategi Pemberdayaan Masyarakat. Penerbit Humaniora: Bandung.

Irawan, Evi, Nana H, Eko P. 2013. Pola Spasial Kemiskinan di Provinsi Jawa Tengah: Suatu Analisis Eksploratif. Jurnal. Surakarta. ISBN: 978-979-636-152-6.

Mahfudz. 2009. Analisis Dampak Alokasi Dana Desa (ADD) Terhadap Pemberdayaan Masyarakat dan Kelembagaan Desa. Universitas Diponegoro. Jurnal. Semarang.

Nurjihadi, M \& Arya. H.D. 2016. Lingkaran setan kemiskinan dalam masyarakat pedesaan, studi kasus petani tembakau di kawasan pedesaan pulau Lombok. Sodality: Sosiologi Pedesaan. Hal 120-127.

Nurwati, N. 2008. Kemiskinan: Model Pengukuran, Permasalahan dan Alternatif Kebijakan. Jurnal Kependudukan Padjajaran. Bandung.

Sahdan, G. 2005. Menganggulangi Kemiskinan Desa. Artikel-Ekonomi Rakyat dan Kemiskinan. Yogyakarta

Sartika, C. Yani, B. \& Wali, A.R. 2016. Studi faktor-faktor penyebab kemiskinan masyarakat desa Lohia Kabupaten Muna. Jurnal Ekonomi. Vol.1(1): 106-118.

Sayogyo. 1977. Garis Kemiskinan dan Kebutuhan Minimum Pangan. 22 Tahun Studi Pembangunan Pengurangan Kemiskinan, Pembangunan Agribisnis dan Revitalisasi Pertanian. Pusat Studi Pembangunan Pertanian dan Pedesaan. LPPM-Institut Pertanian Bogor.

Tobler, W. 1970. A computer movie simulating urban growth in the Detroit region. Economic Geography. 46(2): 234-240.

[UU] Undang - undang Nomer 6 Tahun 2014 tentang Desa.

Prasetyanto, Eko PP. 2012. Dampak Alokasi Dana Desa pada Era Desentralisasi Fiskal terhadap Perekonomian Daerah di Indonesia. Institut Pertanian Bogor. Thesis.

Prawoto, N. 2009. Memahami kemiskinan dan strategi penanggulangannya. Jurnal ekonomi dan studi pembangunan. Volume 9. Nomer 1: 56-68. 